\title{
Anti-viral activity in four species of salmonids following exposure to poly inosinic:cytidylic acid
}

\author{
W. D. Eaton* \\ University of Alaska Fairbanks, Juneau Center For Fisheries and Ocean Sciences, 11120 Glacier Highway, Juneau, \\ Alaska 99801, USA
}

\begin{abstract}
Pink, chum, and sockeye salmon and steelhead trout produced an anti-viral interferon-like response following intraperitoneal injections of the dsRNA synthetic polymer poly inosinic:cytidylic acid (Poly I:C). In all cases, maximum anti-viral titers were reached between 3 and $7 \mathrm{~d}$ post-injection with Poly I:C. Following injection with Poly $\mathrm{I}: \mathrm{C}$, chum and sockeye salmon were challenged with Infectious Hematopoietic Necrosis Virus (IHNV) and chum salmon with Erythrocytic Necrosis Virus (ENV). Fish pretreated with Poly I:C and then challenged with IHNV developed an anti-viral response which resulted in a decreased IHNV titer, lower cumulative mortalities, and a delay in virus replication when compared to untreated fish. The ENV could not be transmitted to chum salmon that had been pretreated with Poly I: C, but was successfully transmitted to untreated fish.
\end{abstract}

\section{INTRODUCTION}

Interferons are glycoproteins that induce cells to synthesize anti-viral proteins that non-specifically inhibit virus replication through several mechanisms (Pestka et al. 1987). The synthetic dsRNA polymer poly inosinic:cytidylic acid (Poly $\mathrm{I}: \mathrm{C}$ ) has been found to stimulate interferon production in primates and in cell culture (Giron et al. 1981, Lampson et al. 1981, Nakamura et al. 1982). Enhanced production of interferon has previously been achieved in the SSE-5, STE-137, KO6, and RTG-2 salmonid cell lines by the introduction of Poly I:C and has resulted in the protection of these cells against Infections Pancreatic or Hematopoietic Necrosis Virus (IPNV or IHNV) (MacDonald \& Kennedy 1979. Tengelsen et al. 1989). de Kinkelin \& Dorson (1973) and Dorson et al. (1975) showed that rainbow trout Oncorhynchus mykiss are capable of producing interferon in response to Viral Hemorrhagic Septicemia Virus (VHSV), and de Kinkelin et al. (1982) showed that exogenous interferon in trout has anti-viral activity.

The non-specific protective components of the fish immune system, such as interferon, can be effective against virus replication and should be considered as

\footnotetext{
- Present address: Biology Department, Malaspina College, 900 Fifth Street, Nanaimo, British Columbia, Canada V9R $5 \mathrm{~S} 5$
}

an essential component in the overall protective response of salmonids. Since interferon-induced inhibition of viral replication is not specific to any one virus, enhancement of this naturally occurring system could result in protection of fish against different viral pathogens. In addition, the interferon-induced anti-viral activity does not involve an antibody response and, presumably, fish need not be immunocompetent to acquire protection. Thus, the induction of the salmonid interferon system may provide a mechanism whereby fry can be protected against different viruses prior to the development of humoral protection.

A study was conducted to determine if steelhead trout (Oncorhynchus mykiss) sockeye (O. nerka), pink (O. gorbuscha), and chum (O. keta) salmon produce an anti-viral response following injection of Poly $\mathrm{I}_{\mathrm{C}_{i}}$ if sockeye and chum salmon are protected against IHNV; and if chum salmon are protected against erythrocytic necrosis virus (ENV) following injection of fish with Poly I:C.

\section{MATERIALS AND METHODS}

Fish. Steelhead trout (mean wt $15 \mathrm{~g}$ ), sockeye (5 g), pink $(1.3 \mathrm{~g})$ and chum $(1.5 \mathrm{~g})$ salmon with no history of IHNV or ENV were received from the National Marine Fisheries Service fish hatcheries at Little Port Walter near Sitka, Alaska or Auke Creek in Juneau, Alaska. 
The fish were tested and found to be ENV and IHNVfree and were maintained in tanks containing $150 \mathrm{gal}$ (570 1) of aerated, static, dechlorinated city water, chilled to $7^{\circ} \mathrm{C}$ for all experiments. Ammonia levels were monitored and kept below 1 ppm total ammonia by water changes every $3 \mathrm{~d}$

Cell cultures and viruses. Stock cultures of RTG-2 cells were kindly provided by the Alaska Department of Fish and Game (ADF\&G) Fish Pathology Laboratory. Cells were propagated at $15^{\circ} \mathrm{C}$ using Eagles Minimal Essential Medium supplemented with $2.0 \mathrm{mM}$ glutamine, $0.01 \mathrm{M}$ HEPES buffer, and either $0 \%$ (EMEM-0) or $7.5 \%$ (EMEM-7.5) fetal bovine serum.

The IHNV strain used was originally isolated from sockeye salmon adults returning to Auke Lake, Alaska in 1978. The virus had been passed 6 times prior to this study and was frozen at $-70^{\circ} \mathrm{C}$. The virus was also provided by the ADF\&G Fish Pathology Laboratory. The ENV used came from liver, kidney, and spleen homogenates of Pacific herring Clupea harengus pallasi experiencing an epizootic due to ENV in Auke Bay, in June, 1989 (Meyers 1989). The liver, kidney, and spleen of 5 herring with cytoplasmic inclusions in $>70 \%$ of their erythrocytes were homogenized in STE buffer $(10 \mathrm{mM}$ Tris- $\mathrm{Cl}, 100 \mathrm{mM} \mathrm{NaCl}, 1 \mathrm{mM}$ EDTA, pH $8.0)$ at a $1: 10$ dilution $(w / v)$ and then frozen and thawed to lyse the cells. The cell debris was pelleted at $2000 \times$ $g$ for $10 \mathrm{~min}$, and the supernatant collected and filtered through a $0.22 \mu \mathrm{m}$ filter. The supernatant was used as inoculum for the ENV transmission study. A similar preparation was prepared from 5 uninfected herring and used as control supernatant.

Anti-viral activity in salmonids. Twenty sockeye, pink, and chum salmon and steelhead trout were injected by the intraperitoneal route with $50 \mathrm{\mu g} \mathrm{g}^{-1}$
Poly I:C (No. P-1530, Sigma Chemical Company) in STE buffer or with $0.2 \mathrm{ml}$ of STE buffer. Five fish from each group were collected on $1,3,5,7,9$, and $11 \mathrm{~d}$ postinjection. The liver, kidney, spleen, and heart were removed from each fish, pooled, and diluted $1: 2(\mathrm{w} / \mathrm{v})$ in sterile STE. The tissues were then macerated and the cell debris pelleted at $2000 \times g$ for $15 \mathrm{~min}$. The supernatant was collected and diluted $1: 5(\mathrm{v} / \mathrm{v})$ in an antibiotic mixture $\left(0.5 \mathrm{mg} \mathrm{ml}^{-1}\right.$ gentamicin, $1 \mathrm{mg} \mathrm{ml}^{-1}$ streptomycin, $50 \mathrm{IU} \mathrm{ml^{-1 }}$ penicillin, $25 \mu \mathrm{g} \mathrm{m} \mathrm{m}^{-1}$ fungizone) and incubated ovemight at $10^{\circ} \mathrm{C}$. The samples were centrifuged again at $2000 \times g$ for $15 \mathrm{~min}$ and the supernatant collected. In an attempt to destroy any anti-viral antibodies present in the samples, an aliquot of the supernatant was frozen at $-70^{\circ} \mathrm{C}$ for $48 \mathrm{~h}$ and thawed, heated to $56{ }^{\circ} \mathrm{C}$ for $30 \mathrm{~min}$, treated with concentrated $\mathrm{HCl}$ to lower the $\mathrm{pH}$ to 2 for $12 \mathrm{~h}$, treated with concentrated $\mathrm{NaOH}$ to raise the $\mathrm{pH}$ to 7.5 , and then dialyzed against cold STE for $12 \mathrm{~h}$. Another aliquot was similarly treated but was also treated with $20 \mu \mathrm{g} \mathrm{ml}^{-1}$ trypsin (Sigma Chemical Company) for 4 h at $37^{\circ} \mathrm{C}$, then dialyzed against cold STE for $12 \mathrm{~h}$.

Serial 2-fold dilutions ( $/ \mathrm{v}$ ) of the treated samples were prepared (to 1:2560) in sterile STE and $1 \mathrm{mI}$ of each dilution was added to replicate monolayers of RTG-2 cells propagated with EMEM-7.5 in 24-well plates (Falcon Laboratories). The cells were incubated for $16 \mathrm{~h}$ at $15^{\circ} \mathrm{C}$, at which time the samples were removed from the cells and the cells washed $3 \times$ in sterile STE. The washed cells were then inoculated with approximately $500 \mathrm{TCID}_{50}$ of IHNV and incubated at $15^{\circ} \mathrm{C}$. Replicate wells, inoculated with sample and no virus, served as cytotoxicity controls. The cells were examined for signs of IHNV-induced CPE daily for 14 $d$, and the results were recorded. The anti-viral titer

Table 1. Oncorhynchus gorbuscha, O. keta, O. nerka and O. mykiss. Anti-IHNV (Infectious Hematopoietic Necrosis Virus) titer in pink, chum, and sockeye salmon and in steelhead trout tissues following intraperitoneal injections of fish with Poly I:C. The antiviral titer is expressed as the reciprocal of the highest dilution of fish tissue homogenate which when added to RTG-2 cells completely inhibited IHNV-induced cytopathic effects

\begin{tabular}{|c|c|c|c|c|c|c|c|}
\hline \multirow[t]{2}{*}{ Inoculation groups } & \multicolumn{7}{|c|}{ Anti-IHNV titer (d post-inoculation) } \\
\hline & 0 & 1 & 3 & 5 & 7 & 9 & 11 \\
\hline \multicolumn{8}{|l|}{ Pink salmon } \\
\hline Prior to trypsin treatment & 0 & 160 & 320 & 640 & 320 & 160 & 0 \\
\hline After trypsin treatment & 0 & 0 & 0 & 0 & 0 & 0 & 0 \\
\hline \multicolumn{8}{|l|}{ Chum salmon } \\
\hline Prior to trypsin treatment & 0 & 0 & 320 & 160 & 160 & 0 & 0 \\
\hline After trypsin treatment & 0 & 0 & 0 & 0 & 0 & 0 & 0 \\
\hline \multicolumn{8}{|l|}{ Sockeye salmon } \\
\hline Prior to trypsin treatment & 0 & 0 & 160 & 320 & 320 & 0 & 0 \\
\hline After trypsin treatment & 0 & 0 & 0 & 0 & 0 & 0 & 0 \\
\hline \multicolumn{8}{|l|}{ Steelhead trout } \\
\hline Prior to trypsin treatment & 0 & 160 & 640 & 640 & 320 & 0 & 0 \\
\hline After trypsin treatment & 0 & 0 & 0 & 0 & 0 & 0 & 0 \\
\hline
\end{tabular}


was recorded as the reciprocal of the highest dilution of sample that resulted in complete inhibition of virus replication.

Virus challenges following exposure to Poly I:C. Sockeye and chum salmon were injected by the intraperitoneal (i.p.) route with $50 \mu \mathrm{g} \mathrm{g}^{-1}$ Poly I:C in STE buffer or with $0.2 \mathrm{ml}$ STE buffer. Four days later, half of the fish in each group were injected i.p. with $4 \times 10^{3}$ TCID $_{50}$ of IHNV and the other half with $0.2 \mathrm{ml}$ EMEM-0. Twenty fish from each of the variously treated groups of each species were held in separate tanks to determine the percent mortalities due to IHNV, and the IHNV titer in all mortalities was determined by TCID $_{50}$ assay as described by Eaton et al. (1989) in order to demonstrate that the cause of death was the virus. In addition, 3 live fish from each treatment group were sampled each week for $5 \mathrm{wk}$ and the IHNV TCID $_{50}$ titer of each pooled 3-fish sample was determined.

Two groups of 30 chum salmon were injected with 50 $\mu \mathrm{g}^{-1}$ Poly I: C in STE buffer or with $0.2 \mathrm{ml} \mathrm{STE} \mathrm{buffer.}$ An additional 2 groups of 30 chum salmon were immersed for $3 \mathrm{~h}$ in water containing $400 \mu \mathrm{g} \mathrm{ml}^{-1}$ Poly I:C. At 4 d post-injection or post-immersion 3 of the variously treated groups of chum salmon were injected with $0.3 \mathrm{ml}$ of the ENV and the other 3 groups were infected with control supernatant from Pacific herring, as described above. Five fish from each group were sampled weekly for $6 \mathrm{wk}$. An individual blood smear from each fish was made on a glass microscope slide and stained with Diff-Quik (Dade Diagnostics, Inc., Aguada, Puerto Rico 00602). Fifty microscopic fields on each slide were examined ( $40 \times$ objective lens) for the presence of intracytoplasmic erythrocytic inclusions characteristic of ENV. Liver and kidney samples were removed from fish with such inclusions and were processed for electron microscopic examination using standard methodologies.

\section{RESULTS}

All 4 species of fish demonstrated the ability to produce an anti-viral response following injections with Poly I: C, with the maximum anti-viral titer occurring 3 to $7 \mathrm{~d}$ post-injection (Table 1). The titrated anti-viral activity was stable at $-70^{\circ} \mathrm{C}$, heat and acid-stable, non-dialyzable, and trypsin-labile. All cytotoxicity controls were negative and no anti-viral activity was evident in control fish injected with STE buffer only (data not shown).

Sockeye and chum salmon that were not treated with Poly I:C demonstrated the first measurable IHNV titers and IHNV-induced mortalities by the second week following IHNV injection (Table 2). The maximum IHNV titers in sockeye salmon occurred by $21 \mathrm{~d}$ postinjection, with maximum cumulative mortalities of $45 \%$ occurring at $28 \mathrm{~d}$. The maximum IHNV titers in chum salmon occurred at $21 \mathrm{~d}$ post-injection, with maximum cumulative mortalities of $40 \%$ occurring at

Table 2. Oncorhynchus nerka and O. keta. Concentration of Infectious Hematopoietic Necrosis Virus (IHNV) in pooled liver, kidney, and spleen samples from live sockeye on chum salmon injected with Poly 1 :C or STE buffer then challenged after $4 \mathrm{~d}$ with IHNV (Auke Creek, Alaska isolate)

\begin{tabular}{|c|c|c|c|c|c|}
\hline \multirow[t]{2}{*}{ Salmon } & \multirow{2}{*}{$\begin{array}{l}\text { Post- } \\
\text { injection } \\
\text { (d) }\end{array}$} & \multicolumn{4}{|c|}{ Treatment } \\
\hline & & Titer $^{c}$ & Mortalities & Titer & Mortalities \\
\hline \multicolumn{6}{|l|}{ Chum } \\
\hline & 7 & 0 & $0 / 20 \quad(0 \%)$ & 0 & $0 / 20 \quad(0 \%)$ \\
\hline & 14 & $5 \times 10^{3}$ & $2 / 20(10 \%)$ & 0 & $0 / 20 \quad(0 \%)$ \\
\hline & 21 & $3 \times 10^{5}$ & $4 / 20(20 \%)$ & $6 \times 10^{3}$ & $1 / 20 \quad(5 \%)$ \\
\hline & 28 & $6 \times 10^{4}$ & $8 / 20(40 \%)$ & $4 \times 10^{3}$ & $1 / 20 \quad(5 \%)$ \\
\hline & 35 & $1 \times 10^{3}$ & $8 / 20(40 \%)$ & $2 \times 10^{2}$ & $2 / 20(10 \%)$ \\
\hline \multirow[t]{5}{*}{ Sockeye } & 7 & 0 & $0 / 20 \quad(0 \%)$ & 0 & $0 / 20 \quad(0 \%)$ \\
\hline & 14 & $2 \times 10^{3}$ & $2 / 20(10 \%)$ & 0 & $0 / 20 \quad(0 \%)$ \\
\hline & 21 & $3 \times 10^{5}$ & $4 / 20(20 \%)$ & 0 & $0 / 20 \quad(0 \%)$ \\
\hline & 28 & $6 \times 10^{5}$ & $9 / 20(45 \%)$ & $1 \times 10^{3}$ & $0 / 20 \quad(0 \%)$ \\
\hline & 35 & $5 \times 10^{4}$ & $9 / 20(45 \%)$ & $3 \times 10^{2}$ & $0 / 20 \quad(0 \%)$ \\
\hline \multicolumn{6}{|c|}{$\begin{array}{l}\text { Fish were injected with } 0.2 \mathrm{ml} \text { of STE buffer, then } 4 \mathrm{~d} \text { later injected with } 4 \times 10^{3} \text { TCID }_{50} \text { IHNV } \\
{ }^{b} \text { Fish were injected with } 50 \mu \mathrm{g} \mathrm{g}^{-1} \text { of Poly I:C in STE buffer and } 4 \mathrm{~d} \text { later injected with } 4 \times 10^{3} \mathrm{TCID}_{50} \text { IHNV } \\
\text { c Concentration of IHNV is expressed as TCID } \mathrm{T}^{-1} \text { of tissue (kidney, liver, and spleen pooled from } 3 \text { live fish) } \\
\text { d Mortalities are expressed as cumulative mortalities over the course of the study. IHNV titers in individual mortalities ranged } \\
\text { from } 2 \times 10^{5} \text { to } 6 \times 10^{5} \text { TCID }_{50} \mathrm{~g}^{-1} \text { of pooled kidney, liver, and spleen }\end{array}$} \\
\hline
\end{tabular}



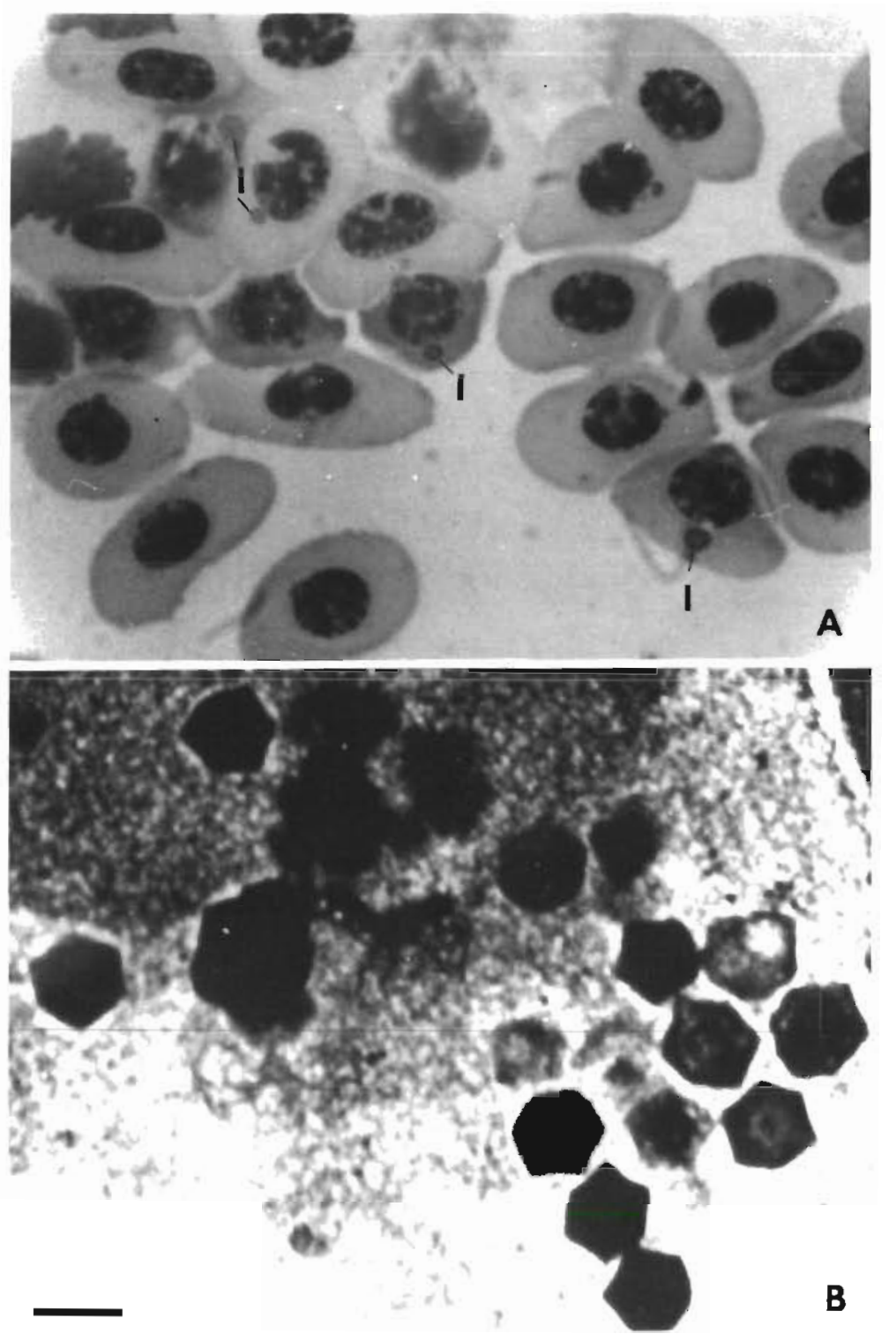

Fig. 1. Oncorhynchus keta. (A) Typical intracytoplasmic inclusion bodies found in the erythrocytes of chum salmon following injection with erythrocytic necrosis virus (ENV) from Pacific herring. I = inclusion bodies; $\times 1000$. (B) Iridovirus-like particles, typical of ENV, found in the inclusion bodies of chum salmon following injection with ENV from Pacific herring. Scale bar $=200 \mathrm{~nm}$
$28 \mathrm{~d}$ post-injection. None of the control fish injected with Poly I:C and STE buffer or with STE buffer followed by injection of EMEM-O developed IHNV infections or experienced any IHNV-related mortalities (data not shown).

Sockeye salmon injected with Poly I:C prior to exposure to IHNV demonstrated initial and maximum viral titers at 28 d post-injection with IHNV. No mortalities occurred in this group of fish. Chum salmon treated with Poly I:C prior to exposure to IHNV exhibited initial and maximum viral titers at $21 \mathrm{~d}$ post-exposure to IHNV and maximum cumulative IHNV-induced mortalities of $10 \%$ by 35 d post-injection (Table 2).

Chum salmon controls injected with ENV after an initial treatment with STE buffer first exhibited cytoplasmic inclusions in the erythrocytes (Fig. 1) at $14 \mathrm{~d}$ post-exposure, the highest prevalence and intensity of infection occurring at $21 \mathrm{~d}$ post-injection (Table 3). At 21 and 28 d post-injection fish exhibiting such inclusions also had petechial hemorrhages at the base of the fins and at the vent. The erythrocytic inclusions were shown by electron microscopy to contain typical ENVlike Iridovirus particles that measured about $190 \mathrm{~nm}$ diameter (Fig. 1).

None of the chum salmon pre-treated either by injection or by waterborne exposure to Poly $\mathrm{I}: \mathrm{C}$ prior to injection with ENV exhibited intracytoplasmic erythrocytic inclusions or any signs of morbidity (Table 3). None of the control fish injected with STE buffer or with Poly I:C followed by injections with the control supernatant developed intracytoplasmic erythrocytic inclusions (data not shown). 
Poly I: $\mathrm{C}$ elicits the anti-viral response. Administration of Poly I: $\mathrm{C}$ by the water-bath route is a more logistically and economically feasible means of inducing an interferon response in fish on a large scale than the injection method. The Poly I:C waterborne exposure method of inducing an interferon-like response needs, however, to be evaluated for its ability to protect very young salmonids against viral pathogens such as IHNV or IPNV. This is important because many hatcheryreared salmonids are lost to viral infections at the stage before they have become immunocompetent.

Although the results of this study are encouraging, more work is needed to determine the efficacy of alternative inducers of the interferon-like response in fish. Poly I: $C$ is expensive, and exposure of fry to Poly I: $C$ on a hatchery-wide scale (even using a bath exposure) may be cost-prohibitive. In addition, Poly I: $\mathrm{C}$ has not been licensed for use as an anti-viral agent on food fish. Giron et al. (1981) used a combination of Amphotericin $\mathrm{B}$, insulin and Poly $\mathrm{I}: \mathrm{C}$ to induce an interferon response in mammalian tissue culture cells. This approach for interferon induction in fish warrants investigation. It is also necessary to determine if an anti-viral response can be induced in sac fry through bath exposures to an inducer. Finally, it would also be interesting to determine if injections of broodstock with inducer would confer any anti-viral protection to progeny fish.

Acknowledgements. This work was supported by the USDA Western Regional Aquaculture Consortium, grant number 87 CRSR-2-3219 and 88-38500-4027. I thank the Alaska Department of Fish and Game, FRED Division, Fish Pathology Laboratory for supplying the cells and virus employed in this

Responsible Subject Editor: Dr T Evelyn, Nanaimo, B.C., Canada study and Dr R. Hedrick, Dr S. Hietala, and Dr J. Leong for editorial comments.

\section{LITERATURE CITED}

de Kinkelin, P., Dorson, M., (1973). Interferon production in rainbow trout (Salmo gairdneri) experimentally infected with egtved virus. J. gen, Virol. 19: 125-127

de Kinkelin, P., Dorson, M., Hattenberger-Baudouy, A. M. (1982). Interferon synthesis in trout and carp after viral infection. Develop. Comp. Immuno. Suppl. 2: 167-174

Dorson, M., Barde, A., de Kinkelin, P. (1975). Egtved virus induced rainbow trout serum interferon: some physicochemical properties. Ann. Microbiol. (Inst. Pasteur) 126B: $485-489$

Eaton, W. D., Wingfield, W. H., Hedrick, R. P. (1989). Prevalence and experimental transmission of the steelhead herpesvirus in salmonid fishes. Dis. aquat. Org. 7: 23-30

Giron, D. J., Smith, K. C., Hoffman, J. A., Fowler, A. K. (1981). Enhancement of viral RNA-induced interferon production in $L$ cells treated with insulin and Amphotericin B methyl ester. J. Interferon Res. 1 (4): 581-586

Lampson, G. P., Field, A. K., Tytell, A. A., Hilleman, M. R. (1981). Poly I:C/Poly-L-Lysine: potent inducer of interferons in primates. J. Interferon Res. 1 (4): 539-549

MacDonald, R. D., Kennedy, J. C. (1979). Infectious pancreatic necrosis virus persistently infects chinook salmon embryo cells independent of interferon. Virology 95: 260-264

Meyers, T. R. (1989). Reoccurrence of VEN epizootics in Alaskan Pacific herring. FHS/AFS Newsletter 17 (2): 9

Nakamura, O., Shitara, N., Matsutani, M., Takakura, K., Machida, H. (1982). Phase I-II trials of Poly (ICLC) in malignant brain tumor patients. J. Interferon Res. 2 (1): 1-4

Pestka, S., Langer, J. A., Zoon, K. C., Samuel, C. E. (1987). Interferons and their actions. Rev. Biochem. 56: 727-77

Tengelsen, L. A., Anderson, E., Leong, J. (1989). Variation in fish interferon-like activity: cell line production and IHN virus isolate sensitivity. FHS/AFS Newsletter 17 (2): 4

Manuscript first received: December 14, 1989

Revised version accepted: August 17, 1990 